\title{
THE USE OF TG IN MANUFACTURING FULL FAT MOZZARELLA CHEESE Metwally, M.M.E. ${ }^{1}$; Hoda Elzeny ${ }^{1}$ and Enas F. Gazar ${ }^{2}$ \\ ${ }^{1}$ Dairy Tech. Dept., Faculty of Agric., Cairo Uni., Giza, Egypt. \\ 2 Food Technology Research Institute, Agriculture Research Center, Giza, Egypt.
}

\begin{abstract}
A method was devised to use transglutamines enzyme (TG) in rennet coagulated cheeses. Two methods of mixing both enzymes were used. Firest Rennet was mixed with milk at $5^{\circ} \mathrm{C}$ for $30 \mathrm{~min}$ followed by the TG at $5^{\circ} \mathrm{C}$ and was left for this before using the temperature to $40^{\circ} \mathrm{c}$ for coagulation. The second method both enzymes were mixed with milk simultaneously at $5^{\circ} \mathrm{C}$ and the mixture was left for 2 hours before raising the temperature to $40^{\circ} \mathrm{C}$. Full fat mozzarella cheese was manufactured using 2 level of TG according to the above first method. The two levels of enzymes $(0.2 \mathrm{~g} / \mathrm{l}, 0.5 \mathrm{~g} / \mathrm{l})$. Mozzarella cheese firmness meltability and stretchability as well as the other physical properties both TG levels. Resulted in softer body \& richer flower. particularly at the $.5 \mathrm{u} / \mathrm{l}$ concentration. From the organoleptic \& physical starcher of mozzarella. The $0.2 \mathrm{u} / \mathrm{l}$ level was recommended
\end{abstract}

\section{INTRODUCTION}

Currently, transglutaminase TG is the only commercial covalent cross linking enzyme available for diary product improvements. Cross - linking reactions may lead to a modification of functional properties of proteins such as solubility emulsifying capacity, foaming and legation prosperities for example, in set yogurt, TG increased gel strength, reduced synerises with a dry smooth gel surface. In Quarg cheese, TG resulted in fewer firms, less grainy and creamier cheese. (Myllarinen et al., (2007), Jaros1 et al., (2006)

Mozzarella chasse has unique functionalities in both unmelted and melted states. In un melted state, credibility to uniform size and over all tsetse and in melted state multiplicity, free oil formation, stretchability and browning are the major functionalities these functionalities (Imm et al., (2003) are governed by various factors such as composition, additives, processing so lido, first content.

Conditions as storage (Pastorino et al., (2003), Sheehan et al., (2004)) of the composition so lido first content sodium chloride \& calcium contents are major factored thigh salt \& low fat caused the hydration of protein, thus seducing the firmness and improving the meltability. For proper mizzen characteristics balance between salt, $\mathrm{Ca} \& \mathrm{pH}$ is needed.

Mozzarella microstructure is formed of protein fibers, as the backbone of the curd, which are Aome what paroled but with dentition due to but globules. Between these protein fifers were channels which are filled with fat globules, bacterial cells and chasse serum. Fat globules forming a noninteracting filler preventing the condense of protein strands (Melko et al., (2004) and Badawi, et al., (2004)

Since TG affects product functionality such as forming smooth, firmer gel with lower why synerises and even resulting more product yield 
Myllarinen et al., (2007),), it definitely would help in improving mozzarella cheese performance.

However, the use of TG for processing ripened cheese facers a coagulation problem. Milk treated with TG does not coagulate with rennet, the enzyme, thought the covalent cross-linking bridges blocks the primary coagulation step prolixity by reducing the accessibility of k-casein in to rennet this is a rteric hindrance effect, particularly TG cross-links the micelle intra molecularly as well as the dissociation of TG-casein in low this problem led scientists do think that it is unlikely that enzymatic modification with TG.

Will be useful in the manufacture of rennet coagulated cheese (Jaros1 et al., 2007) However after finalizing this research, abatement was published on 2005 (Kumazawa et al., 2005) which proposed tow methods for milk coagulation with rennet and TG. Rennet was added to milk kept at low temperature for a period of time, then TG was added and the mixture was kept at cold temperature for a certain period of time then them mature temperature was period for coagulation. In the second method rennet and TG were added simultaneously to milk, the mixture was kept at low temperature for a period of time then the temperature was raised to $30^{\circ} \mathrm{C}$ for coagulation . Therefore this screech was carried out to find a solution of the above problem and device a methods that allows the use of TG in rennet coagulated cheeses- Secondly, the use of TG in processing full fat mozzarella cheese to study, the enzyme modification for cheese properties \& functionality

\section{MATERIALS AND METHODS}

Fresh raw cow's milk was obtained from Dairy Science and Technology Department, Faculty of Agriculture, Cairo Unnivrsity, Giza, .Egypt. Streptococcus salivarius subsp. Thermophilus and lactobacillus dlbruckii subsp. Bulgaricus were obtained from Hansen laboratory (Denmark). Calf rennet powder was obtained from Chr .Hansen's laboratories Denmark. Transglutaminase was a gift from Ajinomoto Europe Sales Gmbh, Hamburg. Dry coarse commercial Sodium chloride was obtained from EL-Nasr Co., Alexandria, Egypt.

Fresh cow's milk was pasteurized $\left(72^{\circ} \mathrm{C} / 15 \mathrm{~s}\right)$ and used form manufacture of mozzarella cheese according to the method of transglutaminase was added to milk with 2 levels $(0.2 \& 0.5 \mathrm{~g} / \mathrm{l}$ of milk) and method of mixing was according to flow diagram in figure (1) cheese was stored at $4^{\circ} \mathrm{C}$ for 28 days. Cheese was sampled at 7, 15,21 \& 28 days for analysis

Moisture, Titratable acidity and salt were determined according to A.O.A.C (1990) ., Fat according to ling (1963) and nitrogen contents and factions using semi-microkieldahl method according to SMEDP (1985).

Meltability of cheese was measured using the meltability test according to Olson and Price (1958) with the modification by Rayan et al., (1980). Cylinders of cheese samples (15g) were put in melting tubes and placed at $110^{\circ} \mathrm{C}$ for $30 \mathrm{~min}$. The distance of flow from the reference line to the 
leading edge of the melting cheese was measured in $\mathrm{cm}$ and recorded as cheese meltability.

The stretchability of Mozzarella cheese was measured using an iron bar test as reported by Davis (1966).

$$
\begin{aligned}
& i_{1}: \text { milk + rennet } \underset{30 \mathrm{~min}}{\stackrel{5^{\circ} \mathrm{C} \text { for }}{\longrightarrow}} \quad \begin{array}{l}
\text { Temperature for coagulation } \\
\text { Raising to } 40^{\circ} \mathrm{C}
\end{array}
\end{aligned}
$$

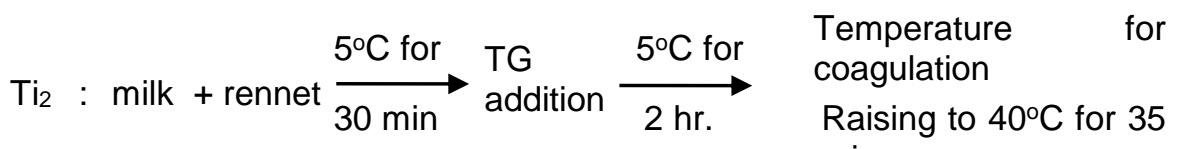

$$
\begin{aligned}
& \text { min. } \\
& \mathrm{Ti}_{2}: \text { milk }+ \text { rennet } \underset{30 \mathrm{~min}}{\stackrel{5^{\circ} \mathrm{C} \text { for }}{\longrightarrow}} \stackrel{\mathrm{TG}}{\text { addition }} \underset{2 \mathrm{hr} .}{\stackrel{5^{\circ} \mathrm{C} \text { for }}{\longrightarrow}} \begin{array}{l}
\begin{array}{l}
\text { Temperature } \\
\text { coagulation } \\
\text { Raising to } 40^{\circ} \mathrm{C} \text { for }
\end{array} 40 \\
\text { min. }
\end{array}
\end{aligned}
$$

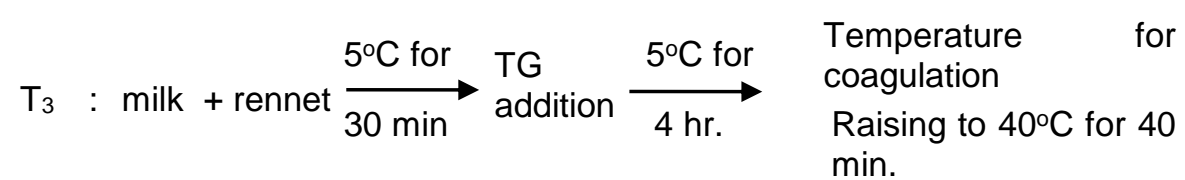

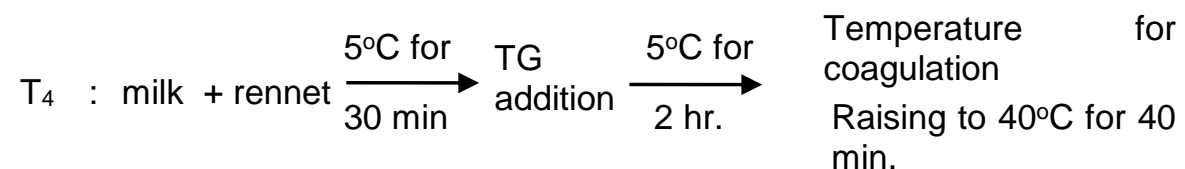

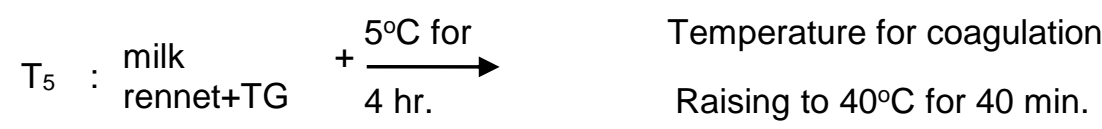

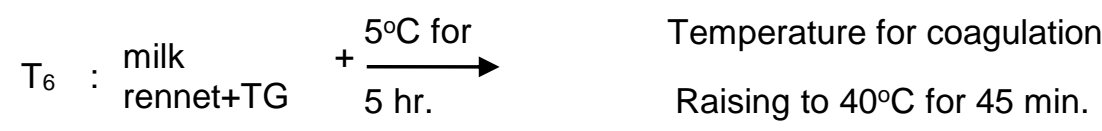

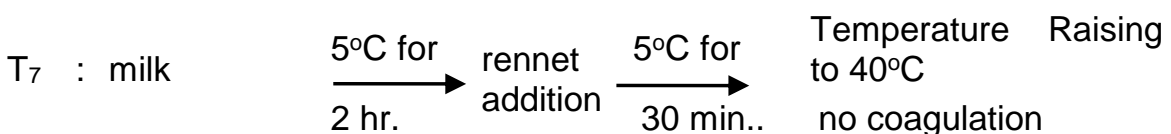

Fig (1): Methods of mixing milk with rennet \& TG and coagulation conditions

The method described by Kindstedt and Fox (1991) was adopted for estimation of free oil (oiling off \%)in melted mozzarella cheese using Gerber fat testing equipment.

Fat leakage of mozzarella cheese was evaluated as described by Bertola et al., (1996) 
Milk viscosity measurements on renneting were carried out in triplicates over temperature of $40^{\circ} \mathrm{C}$ using a concentric cylinder Brookfield Programmable viscometer (Model DV -11+; Brookfield Engineering Laboratories, USA) with UL adaptor and ULA spindle over a shear rate of $12.2 \mathrm{~S}^{-1}$. The milk samples was allowed to tem. At $40^{\circ} \mathrm{C}$ for $10 \mathrm{~min}$. Prior to measurements. Win Gather version 1.1 (Brookfield Engineering Laboratories, Inc., copyright (01995) Software was used to collect. Store and plot the data on a personal computer to the viscometer.

Texture properties of curd (penetration test) and cheese (compression) samples were evaluated using texture analyzer (CNS-Farnell, Borehamwoad, Hertfordshimre, England). Cheese samples presented to the instrument were $1 \pm 0.1 \mathrm{~cm}$ cubes. ATA15-45 Perspex cone was used as the probe with a penetration of $10 \mathrm{~mm}$ at $0.5 \mathrm{~mm} / \mathrm{s}$. Samples were allowed to equilibrate at ambient temperature for approximately 30-45 min prior to testing.

For fxaming cheese microstructure, Cheese cubes $(3 \times 3 \times 10 \mathrm{~cm})$ were prepared from samples of stretched cheese were fixed in $4 \%$ glutaraldehyde in $0.1 \% \mathrm{M}$ phosphate buffer at $\mathrm{pH} 7.2$ for $2 \mathrm{hr}$ to fix the protein. The cubes were washed several times in $0.1 \% \mathrm{M}$ phosphate buffer at $\mathrm{PH} 7.2$ for15 min intervals, then post fixed in $1 \%$ osmium tetroxid $\left(\mathrm{OSO}_{4}\right)$ in $0.1 \mathrm{M}$ phosphate for 1-2 $\mathrm{hr}$ for fat fixation. The cheese samples were re washed several times in $0.1 \mathrm{M}$ phosphate buffer for $15 \mathrm{~min}$ intervals. Then specimens were dehydrated in series of aqueous ethanol solution $(25 \%, 50 \%, 75 \%, 95 \%$ and $100 \%$ ) for $15 \mathrm{~min}$ each. The samples were dried to critical point using $\mathrm{CO}_{2}$ in a Critical point drier (Poland, Waterford, England), and mounted on aluminum SEM stubs, sputter-coated with gold (Spi module sputter coater, spi supplies division of structure probe .inc). Samples were examined at $5 \mathrm{KV}$ through Scanning Electron Microscope JEOL-jsm5200 equipped with an IBMcompatible computer to recording the images.

The actual percentage of calcium, fat and protein recovered in cheese or loosed in whey and stretching water were calculated Theoretical yield was calculated with the modified Van Slyke formula as described by Metzger et al., (2000).The original Van Slyke formula was based on cheddar cheese yield and was modified for mozzarella cheese. The modification included changing the assumed fat recovery from 0.93 to 0.85 and changing the constant factor from 1.09 to 1.13 .

Yield (kilograms $/ 100 \mathrm{Kg}$ of milk $)=[(0.85 \times$ milk fat \% $)+($ milk casein\% -0.1$)$ $\mathrm{x} 1.13$ ] /1-(cheese moisture/100).

Yield efficiency was determined by dividing the actual yield by the theoretical yield multiplied by 100 .

The cheese samples were organoleptically evaluated, by bairy Dept. staff members, score points for flavor, body and textures as well as appearance were $50,35,15$ respectively and this was according to the method of Scott (1981).

The two way statistical analysis of variance (ANOVA), mean separation, correlation and factor factorial was performed by running the MSTAT-C (ver.2.10, Michigan state university, USA.) package on a personal computer .The same program was used to analyze a factorial analysis of 
variance completely randomized design. The statistical significance of the data was determined using $p$ value less than 0.05 .

\section{RESULTS AND DISCUSSION}

Results deal with the following 2 points

a- Methods for the use of TG in rennet coagulation of milk

b- The use TG in processing full fat mozzarella cheese and to study the enzyme modification for cheese properties and functionality.

a- The use of TG in rennet coagulation of milk

Figure (1) shows the schematic diagram of 7 experimental trials for methods of mixing.

Rennet and TG with milk and the procedures followed for coagulation.

These trials were run on two important facts. The first was that rennet and TG works at cold temperatures though at low velocity and the second was that cusion does not coagulate neither with rennet nor acid at cold temperature $\left(5^{\circ} \mathrm{C}\right)$. However the order of mixing both enzymes were found to have an effect, so, if TD is mixed first with milk at $5^{\circ} \mathrm{C}$ for 5 hours and then rennet was added $5^{\circ} \mathrm{C}$ for $30 \mathrm{~min}$, coagulation did not take place when the temperature was raised to $40^{\circ} \mathrm{C}$ so, rennet had to work on k-causin first replacing the glycomacropeptides and then TG cross-linking let to work and this will not inhibit coagulation. Two mixing orders were tried, first rennet was added to milk for 30 min at $5^{\circ} \mathrm{C}$ followed by $\mathrm{TG}$ and the mixture was left for within 2 to or $4 / \mathrm{T} 3$ hours. Before raising the temperature to $40^{\circ} \mathrm{C}$. in this trail milk coagulated in $35 \& 40$ min, respectively. The second order of mixing, rennet \& TG were mixed with milk simultaneously and the mixture was kept at $5^{\circ} \mathrm{C}$ for 2(T4), 4 (T5) and 5 (T6) hrs. Before reusing the temperature for coagulation.

Milk of T4 \& T5 was took $40 \mathrm{~min}$, while TG took $45 \mathrm{~min}$ these results indicated that there is a certain limit for the extent of T6 reaction other wise, coagulation started to be delayed. Actually when the released ammonia was measured as indication of the extant of TG reaction, these was slight increase . of the released ammonia by time (data not shown) Both mixing orders were found to be working and $2 \mathrm{hrs}$ for TG reaction was found to be proper.

Figure (2) presents the effect of the above 6 methods of mixing TG on milk coagulation profile as monitored by viscosity changes until coagulation. Compared to the control, coagulation time shifted to longer period with $T G$ reaction and mixing method.

The control showed the regular coagulation profile of viscosity versus time on rennet action, viscosity increases then there is a slight dip followed by large increase until the coagulum is formed. Viscosity then declined due to coagulum deformation. The figure shows that as TG reaction period increased, coagulation period also increased. Therefore, T2 coagulated faster than T3 and T4 \& T5 \& T6. The coagulation was greatly delayed when TG reaction increased than 2 hrs so T5 \& T6 are interfered in their time of coagulation and the shape of their curve were not normal. Since T2 curve was the closest to the control, it was adapted for mozzarella cheese manufacture. 
Metwally, M.M.E. et al.

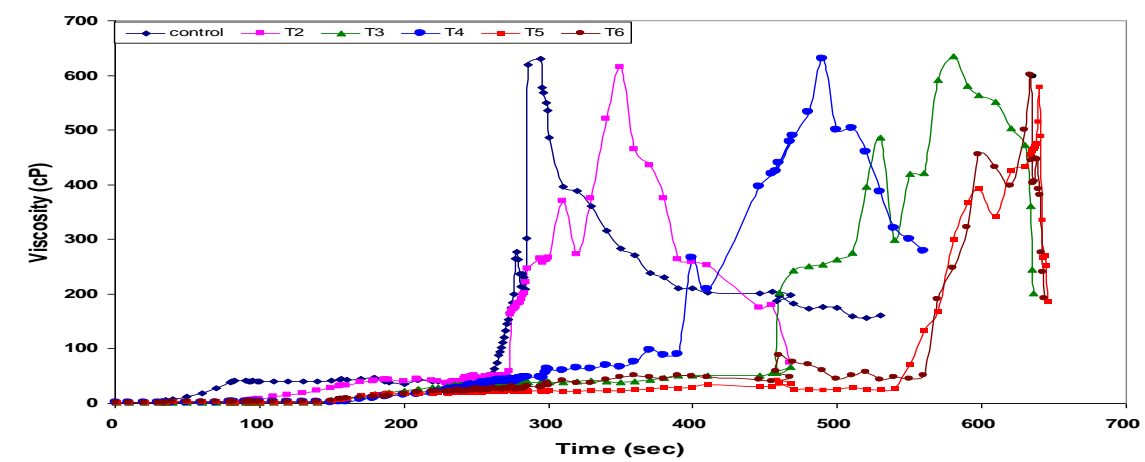

Fig (2).Effect of different coagulation trails on coagulation time and phases of milk coagulation.

b- the use of TG in full fat mozzarella cheese.

Two experimental mozzarella cheese using levels of TG were processed according to the manufacturing flow diagram (Fig3).

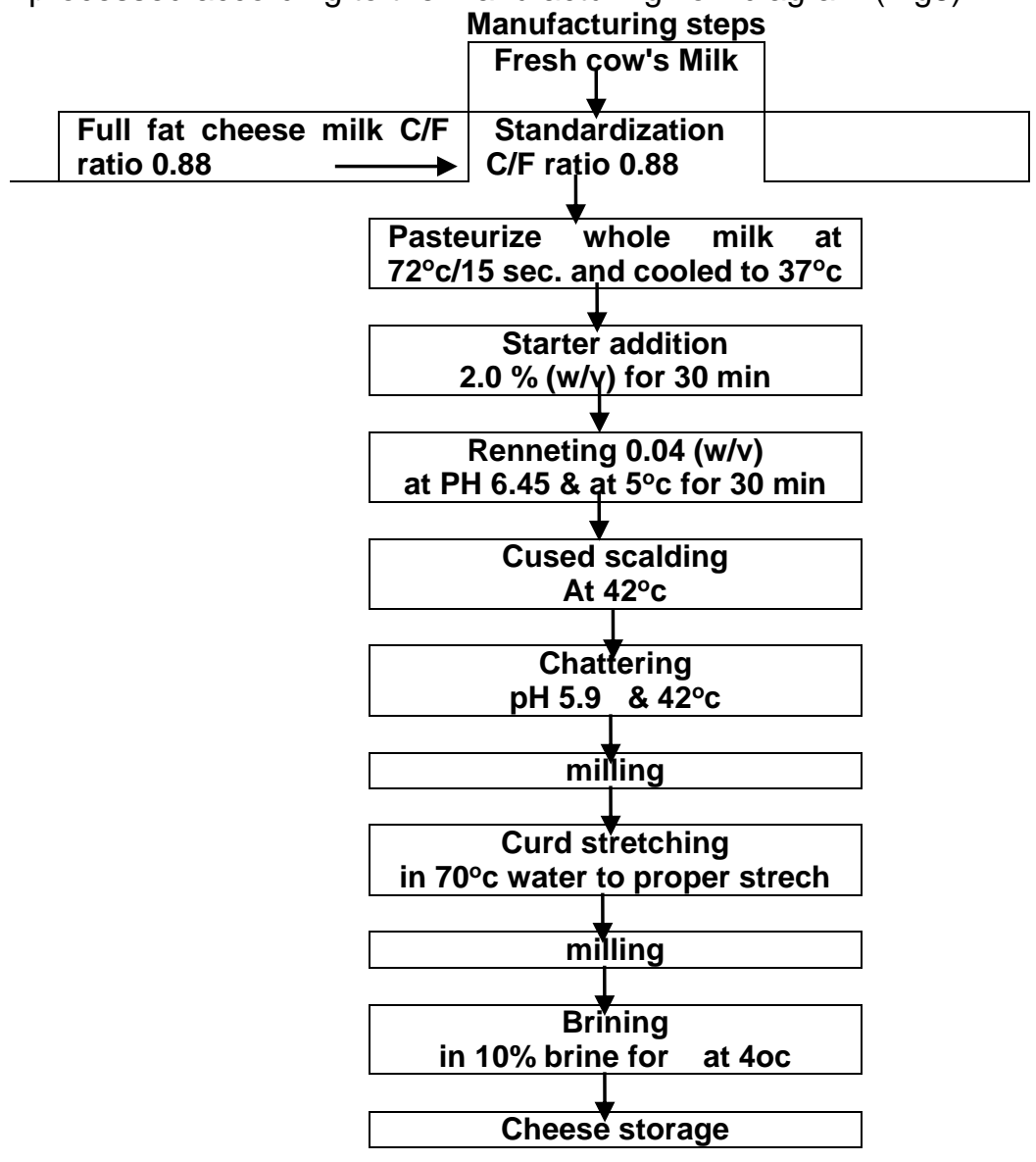

Fig (3) mozzarella cheese manufacture using TG flow diagram 
Table (1) shows cows milk composition \& Table (2) mozzarella cheese composition. As affected by TG addition and changes during cold storage. TG caused significant increase in moisture content fat and TN through storage. Moisture \& fat contented $\mathrm{pH}$ decreased by storage. Cheese soluble \& non-protein nitrogen contents were lower in TG chesses and effect increased by enzyme concentration.

Table (1) cross milk chemical composition

\begin{tabular}{l|c}
\hline Component (\%) & Full fat milk \\
\hline DM & 11.54 \\
Fat & 3.00 \\
F/DM & 26.00 \\
Protein & 3.38 \\
P/DM & 29.30 \\
Casein & 2.64 \\
CN/ DM & 22.88 \\
C:F ratio & 0.88 \\
NPN & 0.22 \\
T.A & 0.17 \\
pH & 6.61 \\
\hline
\end{tabular}

Table (2) effect of TGase enzyme on chemical composition of full fat mozzarella cheese and during storage period.

\begin{tabular}{|c|c|c|c|c|c|}
\hline Treatments & \multicolumn{5}{|c|}{ Storage period,(day) } \\
\hline & Fresh & 7 & 14 & 21 & 28 \\
\hline \multicolumn{6}{|c|}{ Moisture (\%) } \\
\hline Control & $52.16 \mathrm{c}$ & $51.74 d$ & $51.20 \mathrm{e}$ & $50.77 f g$ & $50.03 \mathrm{~h}$ \\
\hline $0.2 \mathrm{TGA}$ & $52.74 b$ & $52.32 \mathrm{c}$ & $51.74 d$ & $51.29 \mathrm{e}$ & $50.67 \mathrm{~g}$ \\
\hline $0.5 \mathrm{TGA}$ & $53.13 a$ & $52.73 b$ & $52.18 \mathrm{c}$ & $51.69 d$ & $50.95 f$ \\
\hline \multicolumn{6}{|c|}{ Fat/DM } \\
\hline Control & 40.76 & 40.95 & 40.99 & 40.89 & $40.61 \mathrm{f}$ \\
\hline $0.2 \mathrm{TGA}$ & $41.12 a b c$ & $41.21 \mathrm{ab}$ & $41.20 a b$ & 41.02 & 40.71 \\
\hline $0.5 \mathrm{TGA}$ & $41.32 a$ & 41.08 & $41.17 a b$ & 40.99 & 40.66 \\
\hline \multicolumn{6}{|c|}{$\mathrm{PH}$} \\
\hline Control & $5.15 \mathrm{abc}$ & $5.10 \mathrm{bcd}$ & 5.05 & 4.98gh & $4.95 \mathrm{~h}$ \\
\hline $0.2 \mathrm{TGA}$ & $5.16 a b$ & $5.11 \mathrm{bcd}$ & $5.07 \mathrm{def}$ & $5.00 \mathrm{fgh}$ & $4.97 \mathrm{~h}$ \\
\hline $0.5 \mathrm{TGA}$ & $5.19 a$ & $5.14 a b c$ & $5.08 \mathrm{cde}$ & 5.02 & 4.98gh \\
\hline \multicolumn{6}{|c|}{ Acidity } \\
\hline Control & $0.67 f g h$ & 0.72 & $0.75 \mathrm{de}$ & $0.78 \mathrm{bcd}$ & $0.86 a b$ \\
\hline $0.2 \mathrm{TGA}$ & $0.63 \mathrm{~h}$ & $0.67 f g h$ & 0.73def & $0.76 \mathrm{cde}$ & $0.84 a b$ \\
\hline $0.5 \mathrm{TGA}$ & $0.62 \mathrm{~h}$ & $0.65 \mathrm{gh}$ & 0.71 efg & $0.75 \mathrm{de}$ & $0.83 a b c$ \\
\hline \multicolumn{6}{|c|}{$\mathrm{TN}$} \\
\hline Control full & $3.37 \mathrm{~h}$ & 3.40gh & $3.43 f g h$ & 3.47 & 3.52 \\
\hline $0.2 \mathrm{TGA}$ & $3.42 \mathrm{fgh}$ & $3.45 \mathrm{efg}$ & 3.49 & $3.53 \mathrm{bcd}$ & $3.58 a b$ \\
\hline $0.5 \mathrm{TGA}$ & r.48 & 3.52 & $3.54 \mathrm{bc}$ & $3.58 a b$ & $3.62 a$ \\
\hline \multicolumn{6}{|c|}{ SN/TN } \\
\hline Control & $4.43 \mathrm{~m}$ & $5.40 \mathrm{j}$ & $6.97 \mathrm{~g}$ & $7.76 \mathrm{~d}$ & $10.11 \mathrm{a}$ \\
\hline $0.2 \mathrm{TGA}$ & $4.27 n$ & $5.13 \mathrm{k}$ & $6.60 \mathrm{~h}$ & $7.74 \mathrm{e}$ & $9.71 \mathrm{~b}$ \\
\hline 0.5 TGA & 4.050 & 4.991 & $6.31 \mathrm{i}$ & $7.23 \mathrm{f}$ & $9.09 \mathrm{c}$ \\
\hline \multicolumn{6}{|c|}{ NPN/TN } \\
\hline Control & $2.14 \mathrm{j}$ & $2.54 \mathrm{~h}$ & $2.95 \mathrm{~g}$ & $3.91 \mathrm{~d}$ & $4.60 \mathrm{a}$ \\
\hline $0.2 \mathrm{TGA}$ & $2.05 \mathrm{k}$ & $2.31 \mathrm{i}$ & $2.52 \mathrm{~h}$ & $3.60 \mathrm{e}$ & $4.18 \mathrm{~b}$ \\
\hline 0.5 TGA & $1.95 I$ & $2.17 \mathrm{j}$ & $2.38 \mathrm{i}$ & $3.37 \mathrm{f}$ & $4.01 \mathrm{C}$ \\
\hline \multicolumn{6}{|c|}{ Salt/M } \\
\hline Control & 2.33hi & $2.41 \mathrm{fg}$ & $2.55 \mathrm{~cd}$ & $2.68 b$ & $2.80 a$ \\
\hline $0.2 \mathrm{TGA}$ & $2.24 \mathrm{jk}$ & 2.34hi & $2.47 e f$ & $2.68 c$ & $2.68 b$ \\
\hline 0.5 TGA & $2.18 \mathrm{k}$ & $2.26 \mathrm{ij}$ & $2.38 \mathrm{gh}$ & $2.51 \mathrm{de}$ & $2.61 \mathrm{bc}$ \\
\hline
\end{tabular}


The yield (table 3 ) increased by the enzyme addition and by its concentration, 0.5 TG concentration gave significant increase (from .2 into $13.6 \%)$. yield efficacies were significantly higher in both TG -chesses. The values were $(99-8,106$ and $110 \%$ for control, .2 \% TG \& 5० TG respectively) Table (4) pints out milk constituents recovery. Significant increase in fat \& protein recovery. With TG cheese over. The control these results are expected due to TG cross-linking action, the enzyme complex whey proteins into casein micelles surface.

Table (3) mozzarella cheese actual and theoretical yield as affected by TGase addition.

\begin{tabular}{l|ccc}
\hline Treatment & $\begin{array}{c}\text { Actual yield } \\
\text { (kg/100kg milk) }\end{array}$ & $\begin{array}{c}\text { Theoretical } \\
\text { yield(kg/100kgmilk) }\end{array}$ & Efficiency (\%) \\
\hline Control full & $12.00 \mathrm{~b}$ & $12.02 \mathrm{~b}$ & $99.83 \mathrm{c}$ \\
0.2 TGA & $12.90 \mathrm{ab}$ & $12.17 \mathrm{a}$ & $106.00 \mathrm{~b}$ \\
0.5 TGA & $13.60 \mathrm{a}$ & $12.27 \mathrm{a}$ & $110.84 \mathrm{a}$ \\
\hline
\end{tabular}

Table (4) Recovery of milk constituents in mozzarella cheese as a function of TGase addition

\begin{tabular}{l|cc}
\hline \multicolumn{1}{c}{ Samples } & Fat recovery $(\%)$ & Protein recovery $(\%)$ \\
\hline Control & $78.0 \mathrm{c}$ & $76.33 \mathrm{c}$ \\
$0.2 \mathrm{TGA}$ & $83.5 \circ \mathrm{b}$ & $83.39 \mathrm{~b}$ \\
$0.5 \mathrm{TGA}$ & $87.81 \mathrm{a}$ & $89.29 \mathrm{a}$ \\
\hline
\end{tabular}

Table (5) the effect is using TG on whey \& starch water

\begin{tabular}{l|ccc} 
a- whey & \multicolumn{3}{l}{} \\
\hline Samples & T.S & Fat & Protein \\
\hline Control & 7.04 & 0.50 & 0.89 \\
0.2 TGA & 6.60 & 0.43 & 0.63 \\
0.5TGA & 6.38 & 0.33 & 0.40 \\
\hline
\end{tabular}

\begin{tabular}{l|cc}
\hline \multicolumn{1}{l}{ b- Stretch water } & & \\
\hline \multicolumn{1}{c}{ Samples } & Fat & Protein \\
\hline Controlfull fat & 0.70 & 0.08 \\
0.2 TGA & 0.40 & 0.06 \\
$0.5 \mathrm{TGA}$ & 0.27 & 0.03 \\
\hline
\end{tabular}

More over cross-linking casein strengthen its fibers network these harvesting more moisture , fat \& protein \& other components, the effect was also manifested in SH/TN \& NPN/TN ratios. The effect was clear in Table(5) which shows why \& stretch water composition less fat \& protein lost in both fluids, when \& water.

Table (6) illustrates the functional stretchability \& melt ability which are important properties of mozzarella are significantly increased by TG treatment and by enzyme concentration and the trend progressed by storage, stretchability increased from 160 into $200 \& 220 \mathrm{~cm}$ in the control, 2 TG \& 0.5 $\mathrm{TG}$, respectively, meltability also improved from 55 in the control cheese into $468 \& 73 \mathrm{~mm}$ in .2 \& .5 TG . chesses. There was no effect of the enzyme on oiling off property. However TG reduced fat leakage.

Table (7) illustrates the analysis of variance of cheese chemical composition \& properties, and table(8) shows the analysis of variance of different coagulation trials. 
Table (6). Effect of TGase enzyme on functional properties of full fat Mozzarella cheese

\begin{tabular}{|c|c|c|c|c|c|}
\hline Treatments & \multicolumn{5}{|c|}{ Storage period (day) } \\
\hline & Fresh & 7 & 14 & 21 & 28 \\
\hline \multicolumn{6}{|c|}{ Stretchability $(\mathrm{cm})$} \\
\hline Control full & $160 n$ & $170 \mathrm{~m}$ & 183 & $213 i$ & $233 f$ \\
\hline $0.2 \mathrm{TGA}$ & $200 \mathrm{k}$ & $210 j$ & $223 g$ & $241 e$ & $259 c$ \\
\hline 0.5 TGA & $220 h$ & $234 f$ & $247 d$ & $267 b$ & $278 a$ \\
\hline \multicolumn{6}{|c|}{ Meltability (mm) } \\
\hline Control full & $55 f$ & 63ef & 72 & 79 & $87 a b c$ \\
\hline $0.2 \mathrm{TGA}$ & 68def & 75 & 80 & 86 & $93 a b$ \\
\hline $0.5 \mathrm{TGA}$ & 73 & 81 & 86 & $93 a b$ & $100 \mathrm{a}$ \\
\hline \multicolumn{6}{|c|}{ Oil off \% } \\
\hline Control full & $4.25 \mathrm{e}$ & $4.42 \mathrm{de}$ & $4.78 \mathrm{c}$ & $5.20 \mathrm{~b}$ & $5.70 \mathrm{a}$ \\
\hline $0.2 \mathrm{TGA}$ & $4.22 \mathrm{e}$ & $4.35 \mathrm{de}$ & $4.63 \mathrm{~cd}$ & $4.97 \mathrm{~cd}$ & $5.63 a$ \\
\hline $0.5 \mathrm{TGA}$ & $4.22 \mathrm{e}$ & 4.33de & $4.59 \mathrm{~cd}$ & $4.90 \mathrm{bc}$ & $5.58 a$ \\
\hline \multicolumn{6}{|c|}{ Fat leakage (mm) } \\
\hline Control full & $57 \mathrm{~h}$ & $64 f$ & $73 \mathrm{~cd}$ & $80 b$ & $85 a$ \\
\hline $0.2 \mathrm{TGA}$ & $55 h$ & $60 \mathrm{~g}$ & $68 \mathrm{e}$ & $74 \mathrm{~cd}$ & $79 b$ \\
\hline $0.5 \mathrm{TGA}$ & $51 i$ & $57 \mathrm{~h}$ & $64 f$ & $72 d$ & $75 \mathrm{c}$ \\
\hline
\end{tabular}

Table (7) Analysis of variances of mozzarella cheese - TG cheese chemical compassion \& probabilities

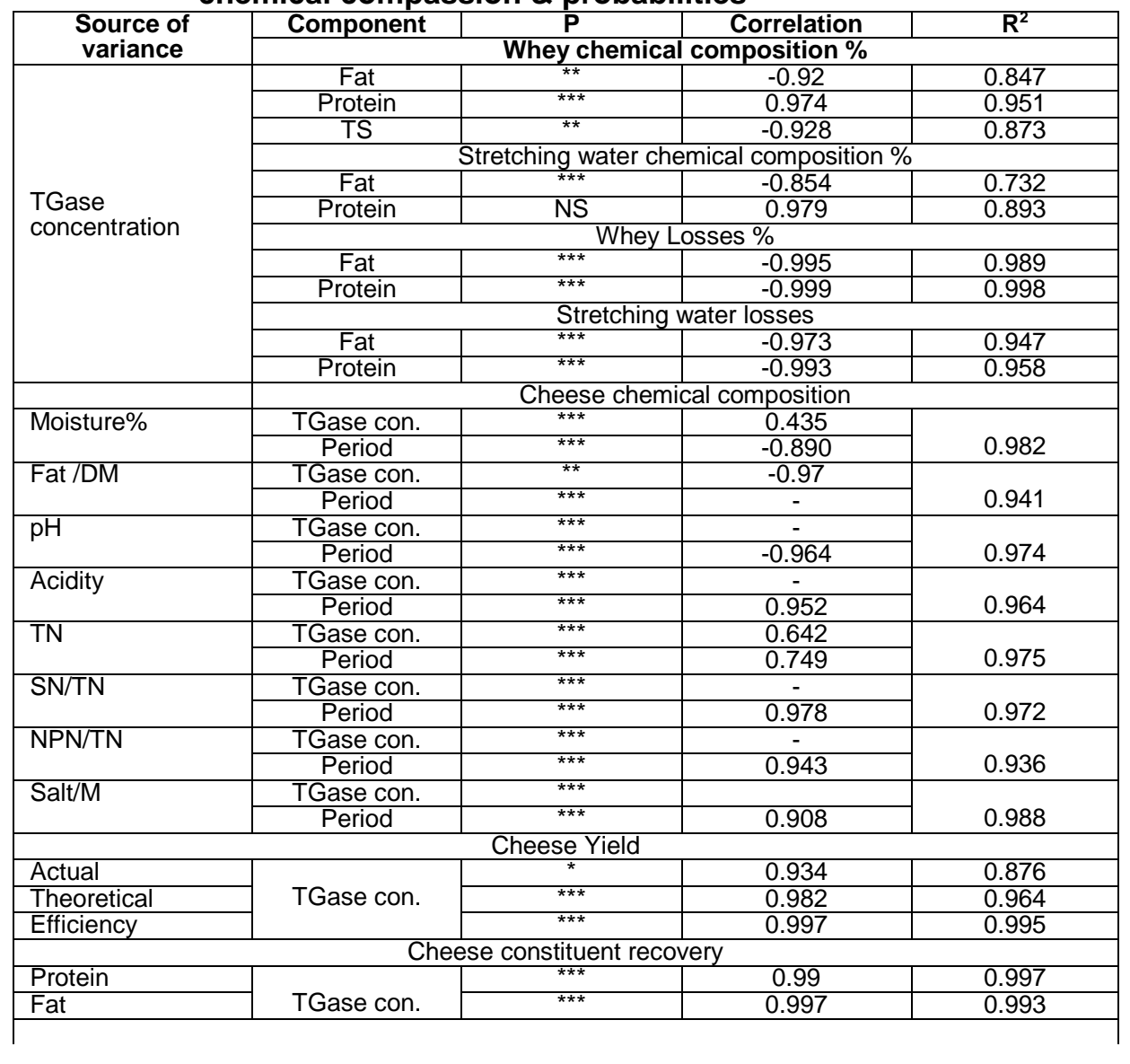


Metwally, M.M.E. et al.

continue Table (7)

\begin{tabular}{|c|c|c|c|c|}
\hline \multicolumn{5}{|c|}{ Cheese Functional properties } \\
\hline Stretchability & TGase con. & 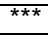 & 0.706 & \multirow[t]{2}{*}{0.974} \\
\hline & Period & $* \star *$ & 0.69 & \\
\hline \multirow[t]{2}{*}{ Meltability } & TGase con. & $\star \star \star \star$ & - & \multirow[t]{2}{*}{0.734} \\
\hline & Period & $* \star *$ & 0.709 & \\
\hline \multirow[t]{2}{*}{ Oil Off } & TGase con. & ** & - & \multirow[t]{2}{*}{0.839} \\
\hline & Period & $\star * *$ & 0.909 & \\
\hline \multirow[t]{2}{*}{ Fat Leakage } & TGase con. & $\pi \star \star \star$ & 0.536 & \multirow[t]{2}{*}{0.98} \\
\hline & Period & $\star \star \star *$ & 0.832 & \\
\hline \multicolumn{5}{|c|}{ Cheese Texture } \\
\hline Hardness & \multirow{7}{*}{ TGase con. } & $\star \star \star \star *$ & -0.997 & 0.995 \\
\hline Gumminess & & 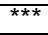 & -0.908 & 0.825 \\
\hline Cohesiveness & & $\star *$ & -0.873 & 0.759 \\
\hline Springiness & & $\star *$ & -0.952 & 0.918 \\
\hline Modulus & & $\star * *$ & -0.99 & 0.998 \\
\hline Adhesiveness & & 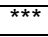 & -0.941 & 0.886 \\
\hline Chewiness & & $* \star \star *$ & -0.941 & 0.886 \\
\hline
\end{tabular}

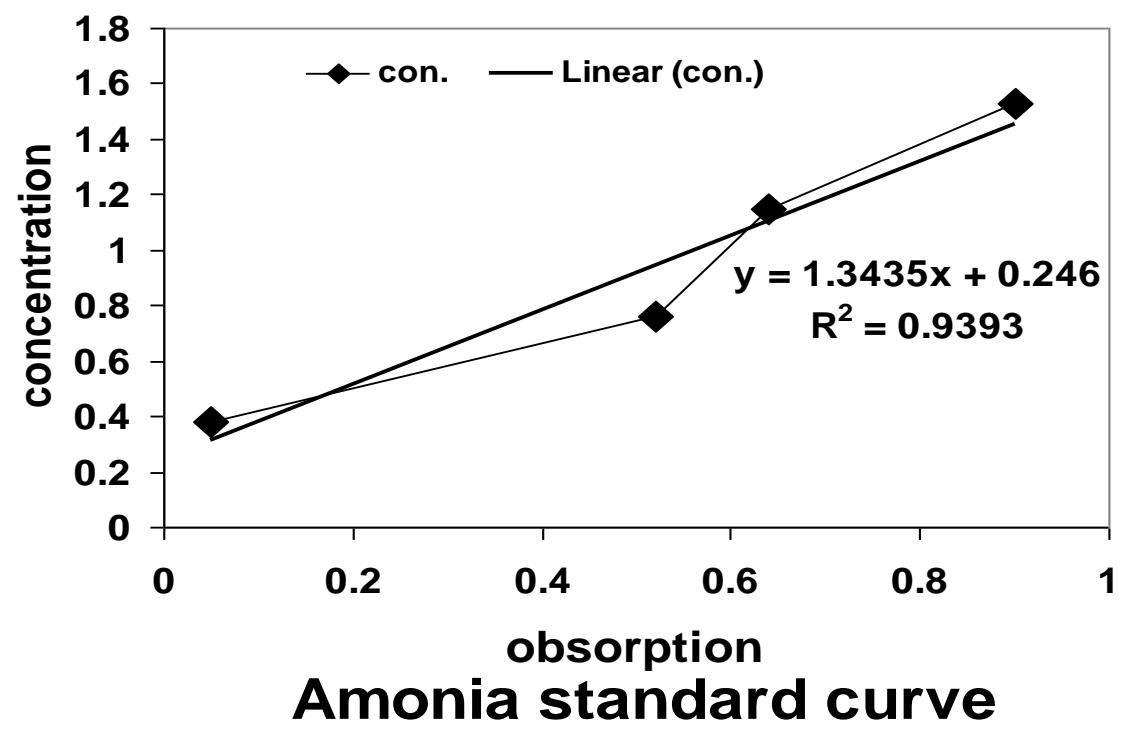

Table (8): Analysis of variance of curd texture of different coagulation trails

\begin{tabular}{|c|c|c|c|c|}
\hline \multirow{2}{*}{$\begin{array}{l}\text { Source of } \\
\text { variance }\end{array}$} & Component & $\mathbf{P}$ & Correlation & $\mathbf{R}^{2}$ \\
\hline & \multicolumn{4}{|c|}{ Cheese Texture } \\
\hline Hardness & \multirow{5}{*}{$\begin{array}{l}\text { Coagulation } \\
\text { trails }\end{array}$} & $\star \star \star *$ & 0.962 & 0.925 \\
\hline Gumminess & & *** & -0.966 & 0.939 \\
\hline Cohesiveness & & *** & -0.946 & 0.902 \\
\hline consistency & & NS & - & - \\
\hline Modulus & & $\star \star \star *$ & 0.971 & 0.943 \\
\hline
\end{tabular}

Fig(4) illustrates texture analysis of TG cheeses as compared with the control the TG enzyme particularly at 0.2 level improved the cheese physical properties followed by the 0.5 level with significant differences springiness. 


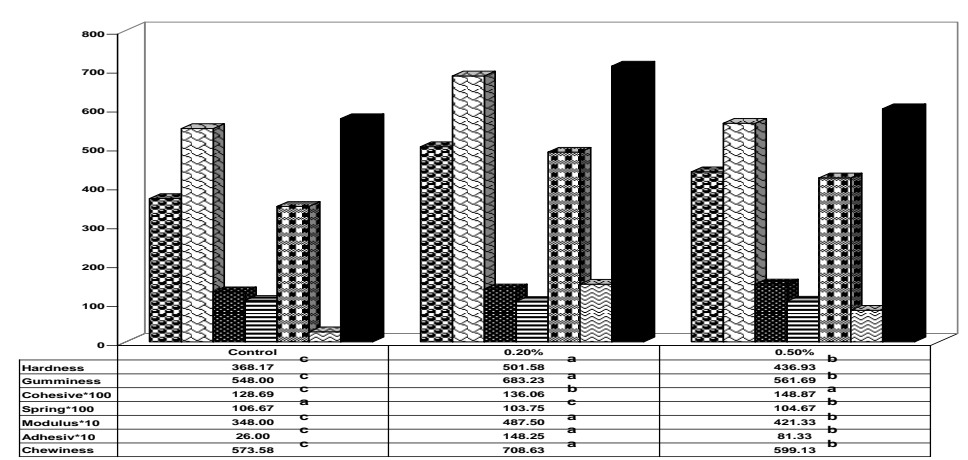

Fig (4): Texture profile of full fat Mozzarella cheese made with TGase enzyme

Table (9) presents the organolypeptic properties of TG chesses. The chesses compared well with the control.

Table (9):Effect of TGase enzyme on organoleptic properties of full fat Mozzarella cheese

\begin{tabular}{|l|c|c|c|}
\hline \multicolumn{1}{|c|}{ Organoleptic properties } & Control & 0.2 TGA & 0.5 TGA \\
\hline Flavor (50) & $44 a$ & $42 \mathrm{a}$ & $43 \mathrm{a}$ \\
\hline Body and texture (35) & $33 \mathrm{a}$ & $35 \mathrm{a}$ & $34 \mathrm{a}$ \\
\hline Appearance (15) & $14 \mathrm{a}$ & $14 . \mathrm{a}$ & $14 \mathrm{a}$ \\
Total & 91 & 91 & 91 \\
\hline
\end{tabular}

However TG imports strong softening effect on the cheese, particularly the 0.5 level. However, the 2 level was proffered by this is expected from the judges high moisture \& contents. In general, TG work usually produces suffer gel with finer particles and with less tendency for 2 moisture .

Fig $(6, a, b, c)$ presents cheese microstructure as viewed by electrons microscope. The control exhibited regular mozzarella structure, protein fibers were some what parallel with smooth surface and their existed between the fibers channels filled with cheese serum containing fat globules. In cheese with $.2 \%$ protein fibers intercrossing forming a close net causing the fat to surface on the fiber matrix giving richer flover \& softer body. TG at 0.5 level fat surfacing and covering all the cheese fiber matrix giving even softer body than the .2 TG level. In conclusion, the devised method for using TG in rennet coagulated cheeses proved to be working mixing milk with rennet at $5^{\circ} \mathrm{C}$ for 30 min then TG is added at $5^{\circ} \mathrm{C}$ and left for 2 hours to work before the temperature is raised to $40^{\circ} \mathrm{C}$ for coagulation. On rennet \& TG were mixed with milk simultaneously at $5^{\circ} \mathrm{C}$ and the mixture was left for $2 \mathrm{hrs}$ then temperature was raised to $40^{\circ} \mathrm{C}$ are the two devised methods. TG enzyme cannot be added before rennet nor the work of the enzyme should be longer than 2 hur. Mozzarella cheese hardness \& melting \& stretch ability properties were improved by using the enzyme. TG level of $0.2 \mathrm{u} / \mathrm{g}$ gave the best results organolyptically as well as the other physical prosperities Actually, the enzyme accentuate the effect of fat in cheese and increased the retention of more overture Both components helped cheese mutability \& stretchability. 
Metwally, M.M.E. et al.

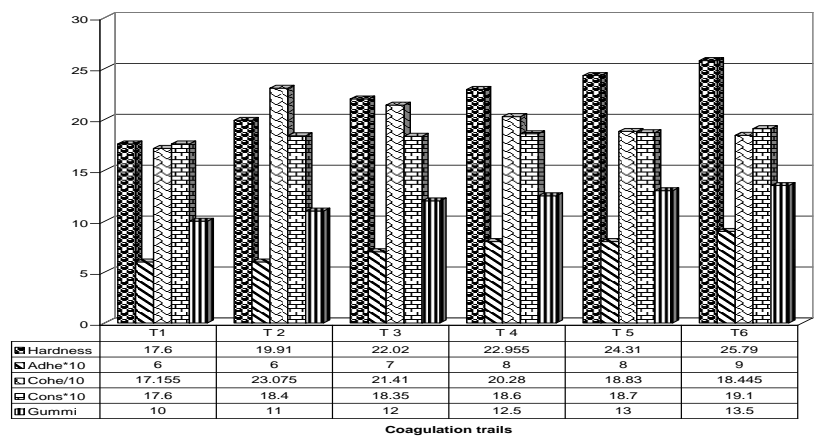

fig (5): Effect of different coagulation trails on the texture of Mozzarella cheese curds
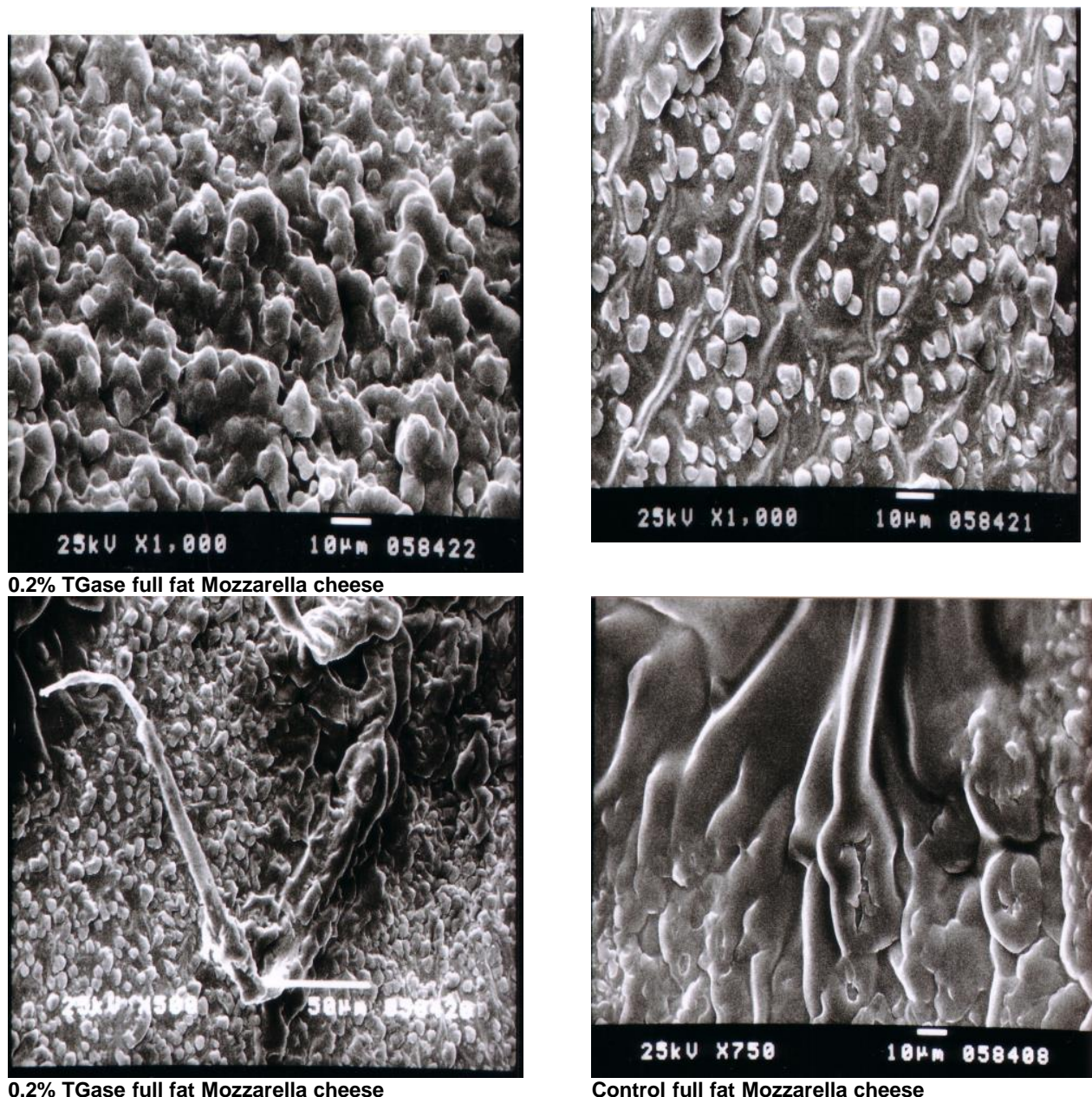

fig (6): cheese microstructure as viewed by electron microcobe 


\section{REFERENCES}

Association of Official Agriculture Chemists. (AOAC) (1990) Official methods of analysis Washington D.C.

Badawi, R.M; S.I. Farag; A..I Okasha\& Mamara (2004). Changes in rheological properties and microstructure during storage of low fat Mozzarella cheese . Egyption .J. Dairy Sci., 32: 341-353.

Bertola, N.C. , Califano, A .N, Bevilacqua, A. E. and Zaritzky, N.E. (1996) Effect of freezing conditions on functional properties of low moisture mozzarella cheese J. Dairy Sc.79:185-190

Davis, J.G. (1966). Cheese Vol. 2. Made and printed by the white Friars Press LTD. London \& Tonbride, U.K.

Guinee, T.P.; Feeney, E.P.; Auty, M.A.E. and Fox, P.F. Effect of pH and Calcium Concentration on Some Textural and Functional Properties of Mozzarella Cheese J. Dairy Sci. 85:1655-1669

Imm, J.Y; Oh, E. J.; Han, K.S.; Oh, S.; Park, Y.W. and Kim, S. H. (2003) Functionality and Physico-Chemical Characteristics of Bovine and Caprine Mozzarella Cheeses during Refrigerated Storage J. Dairy Sci. 86:2790-2798

Jaros1, D.; Partschefeld, C.; Henle, T. and Rohm1, H. (2006) Transglutaminase in dairy products: chemistry, physics, applications Journal of Texture Studies (37) 113-155

Kindstedt, P. S. and Fox, P. F. (1991). Modified Gerber test for free oil in melted mozzarella cheese J. Food Sci., 56(4) 1115-1116.

Kumazawa et al., (2005) Process for producing cheese curd. United States Patent Application Publication No.: US 2005/0123645 Al

Ling E. R. (1963).Text book of dairy chemistry vol. I I practical, 3 th Ed. Chapman and Hall LTd. London

Melko, S.W., Gustaw, P. Glibowski and J. Pielecki (2004). Stress relaxation study of UF-milk chese with transglutaminase. Egyption J. Dairy Sci., 32:237-244.

Metzger, L. E.; Barbano, D. M; Rudan, M. A and Kindstedt, P. S.(2000) Effect of milk pre-acidification no low fat mozzarella cheese. I. Composition and yield. J. Dairy Sci. 83:648-658.

Myllarinen, P.; J. Buchest\& K. Autie. (2007). Effect of transglutminase on Rheological properties and microstructure ofchemically acidified sodium caseinate gels. Int. Dairy J. 17 (7):800-807.

Olson, N.F. and Price, W.V. (1958) A melting test for pasteurized process cheese spreads. J. Dairy Sci., 41: 999-1000.

Pastorino. A. J., N.P. Ricks, C.L. Hansen and D.J. McMahon. (2003).Effect of calcium and water injection on structure-function relationship of cheee.J. Dairy Sci., 86:105-113

Rayan, A. A.; Kalab, M. and Ernstrom, C. A., (1980). Microstructure and rheology of process cheese Scanning Electron Microscopy (1980), No.3, 635-643 C.f. Dairy Sci. Abstr.43:7856. 
Metwally, M.M.E. et al.

Rowney, M.K.; Hickey,M.W.; Roupas, P. and Everett,D.W.(2003) The Effect of Homogenization and Milk Fat Fractions on the Functionality of Mozzarella Cheese J. Dairy Sci. 86:712-718

Scott, R. (1981). Cheese making practice Applied Sci publisher Ltd. London

Sheehan J.J., O. Kathleen, T.P. Guinee (2004). Effect of coagulation type and storage temperature on the functionality of reduced-fat Mozzarella cheese. Lai 84: 551-566

إستخدام إنزيم الترانس جلوتاميناز فى تصنيع جبن الموزريلا كاملة الدسم

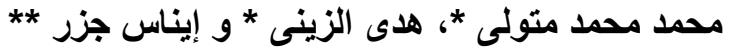

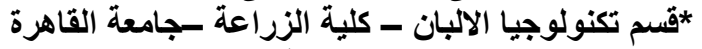
* * معهز بحوث تكنولوجيا الاغذية - مركز البحوث الزراعية بالجيزة

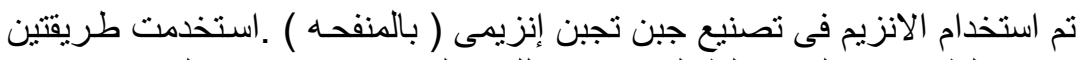

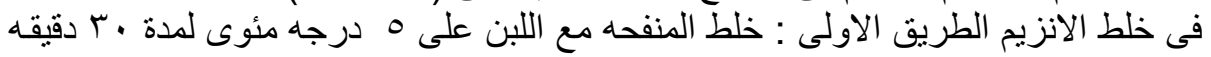

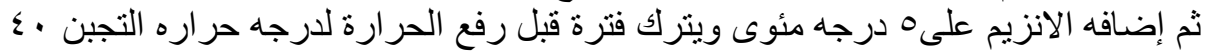

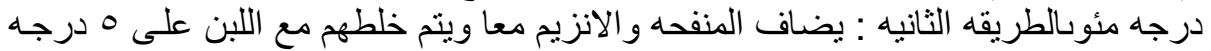

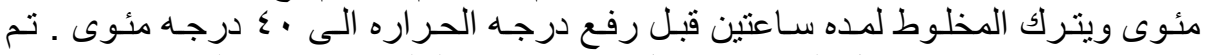

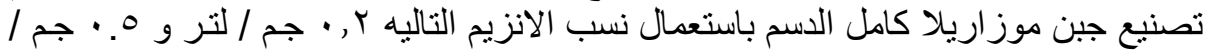

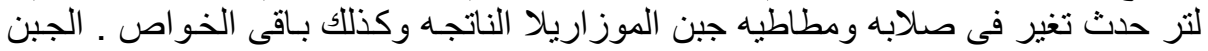

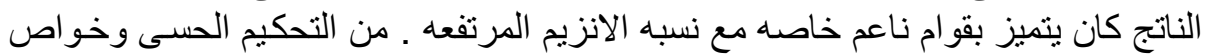

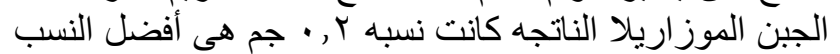

